\title{
Ethan Kleinberg: Theory of History as Hauntology
}

\section{Ethan Kleinberg: Teoria da História como Fantologia}

\author{
André da Silva Ramos* \\ andramos7@gmail.com \\ PhD Candidate \\ Universidade Federal de Ouro Preto \\ Rua do Seminário, s/n - Centro \\ 35420-000 - Mariana - Minas Gerais \\ Brazil
}

\section{Keywords}

Theory of History; History of Historiography; Hauntology.

\section{Palavras-chave}

Teoria da História; História da Historiografia; Fantologia.

Received in: 9/12/2017

Approved in: 12/19/2017

\begin{abstract}
${ }^{*}$ I would like to thank Fulbright/CAPES for funding me during the academic year of 2015-2016 at Stanford University as a visiting student researcher. In Stanford, I was advised by Professor Hans Ulrich Gumbrecht, who encouraged me to spend the month of June of 2016 at Wesleyan University to work with Professor Ethan Kleinberg. I would like to thank Professor Gumbrecht for his kind advice and generosity. Professor Gumbrecht's guidance was fundamental during my entire research internship at Stanford University. I would also like to extend my gratitude to Professor Ethan Kleinberg; in addition to this interview, we met several times to discuss my PhD research. I would like to thank as well my PhD colleagues, André Luan Nunes Macedo and Liliana Mendoza Ortiz, of the Nucleus of History of Historiography and Modernity at Federal University of Ouro Preto (NEHM/UFOP), who translated this interview into Portuguese and Spanish and Júlia de Melo Arantes, for helping me with the proofreading. In addition, the questions I raised then were connected with the debates surrounding NEHM/UFOP's agenda in the last decade. Therefore, I would like to extend my gratitude to all professors, graduate, and undergraduate students that formed this exciting intellectual environment, especially my advisor Professor Valdei Lopes de Araujo and Professor Marcelo de Mello Rangel.
\end{abstract}


Ethan Kleinberg is Professor of History and Letters at Wesleyan University, director of its Center for Humanities and editor-in-chief of its journal History and Theory. His first book, Generation Existential: Heidegger's Philosophy in France, 1927-1961, published by Cornell University Press, was awarded the 2006 Morris D. Forkosch prize for best book in the category intellectual history by the Journal of the History of Ideas. Recently, Professor Kleinberg co-edited with Ranjan Ghosh the volume Presence: Philosophy, History, and Cultural Theory for the $21^{\text {st }}$ Century, published by Cornell University Press. His book, Haunting History: For a Deconstructive Approach to the Past, was released in the Meridian Series of Stanford University Press in the fall of 2017. He is also finishing The Myth of Emmanuel Levinas, centered on the Talmudic Lectures that this FrenchJewish philosopher held in Paris between 1960 and 1990. I had the opportunity to conduct an interview with Professor Kleinberg in June 2016, when I was a visiting student researcher at the Center for Humanities at Wesleyan University. I also seized the Second International Network for Theory of History Conference ( $2^{\text {nd }}$ INTH) in Ouro Preto, Brazil, from August 23 to August 26, 2016, to expand the interview and to record a short version of it. ${ }^{1}$

1. André da Silva Ramos: Professor Kleinberg, please speak about how your interest in the field of Theory of History emerged and affected your career?

Ethan Kleinberg: When I started as an undergraduate at UC Berkeley, my focus was on philosophy and I believed I would become a philosophy major. But the deeper I got into philosophical issues the more I realized that my real interest was in the relation between intellectual thought and historical context. This led me to write my senior thesis with Martin Jay as an interdisciplinary humanities major. After completing my undergraduate degree, I knew I would attend graduate school and again faced a decision as to which discipline to pursue. Given my interest in history and because the philosophers that caught my attention - Heidegger, Benjamin, Foucault, Derrida, and Kristeva- were all of the continental tradition, which is less taught in USA philosophy departments, I decided to pursue intellectual history in graduate school. I entered the PhD program at UCLA and it was there that I developed my interest and passion for theory of history. I was being trained as a European intellectual historian with a focus on continental philosophy but this was also right after the famous conference on the Holocaust at UCLA that led to the volume edited by Saul Friedländer, Probing the Limits of Representation. I was part of a cohort that was as interested in the form and theory of history as in the pursuit of historical case studies and we would meet in the library to discuss the latest issue of History

\footnotetext{
${ }^{1}$ On the occasion of the Second International Network for Theory of History Conference ( $2^{\text {nd }}$ INTH), in Ouro Preto, Brazil, from August 23 to August 26, I had the opportunity to record a short version of this interview. It was a pleasure to be part of the Brazilian Society of Theory and History of Historiography's (SBTHH) organizing committee, headed by Professors Marcelo Abreu, Andre de Lemos Freixo, Valdei Lopes de Araujo, Helena Mollo, Marcello de Mello Rangel, Julio Bentivoglio, and Pedro Caldas, responsible for hosting the $2^{\text {nd }}$ INTH at Federal University of Ouro Preto (UFOP). I would like to thank the TV UFOP's coordinator, Fernanda Luiza Teixeira Lima, and its crew for making it possible. It can be watched in the following link: <https://www. youtube.com/watch?v=PH9q_bJboHs>.
} 
and Theory. I worked closely with Professors Robert Wohl, Saul Friedländer, Peter Lowenberg, and David Myers but also took classes in the Comparative Literature department. I benefited from the presence of Carlo Ginzburg, Perry Anderson, Eugen Weber and then later Lynn Hunt. My interest in the work of Heidegger led me to Samuel Weber, who was teaching in the Comparative Literature department, and Jacques Derrida, who was teaching at UC Irvine. I also met Dominick LaCapra and Michael Roth who were not at UCLA but were very generous with their time and support. Thus I walked a sort of tightrope between intellectual history and theory of history where I read figures such as Hegel, Benjamin, Rosenzweig, Heidegger, and Kojève as both templates for theory of history and actors in intellectual history. I should say that the courses I took with Sam Weber and Jacques Derrida were incredibly influential in helping me think about the theory of history in a different light and using different tools. To this day I recommend that all students pursuing graduate studies move outside of their chosen discipline to get outside the field and understand multiple logics of scholarship and understanding.

\section{A. S. R.: Could you speak a little bit about your first book, on Heidegger's reception in France?}

E. K.: Generation Existential: The Reception of Heidegger's Philosophy in France, 1927-61 was based on my dissertation. When I began the project I was

214 initially interested in reactions to Heidegger's philosophy in Germany before and after World War II. But as my research progressed I realized there was a much more historical issue at play in regards to the reception and dissemination of Heidegger's work in France. Specifically, what interested me were the ways that Heidegger's philosophy was appropriated by predominantly left wing thinkers in France despite Heidegger's well known affiliation with National Socialism. I argued that the reception process in France was governed by a double logic of heimisch and unheimlich wherein Heidegger's philosophy was appropriated in ways that made it at home in France but also retained a kernel of the unfamiliar rendering it somehow permanently foreign as well. Using the template of three different "readings" of Heidegger's philosophy I was able to move away from the issue of whether the French thinkers got Heidegger's philosophy "right" or "wrong" (an argumentative strategy that characterizes that successive Heidegger Affairs in France) and instead focus on the ways that ideas move across time, language, and space. These three readings are the existentialist interpretation of the 1930s and early 1940s, heavily influenced by Kojève's Heideggerian reading of Hegel and consolidated by Sartre's phenomenological ontology; a postwar emphasis on Heidegger, revolving around Jean Beaufret, that argues against the French existentialist reading in order to stress Heidegger's concern with the history of metaphysics and the forgetting of Being; and finally, the critique of Heidegger's thought advanced by Blanchot and Levinas in the light of the Shoah and Heidegger's complicity with the Nazi regime. In the end, and as Dominick LaCapra noted, the larger goal was to argue that the different readings and 
responses to Heidegger's philosophy have always been more or less intricate and coded responses to larger social, political, and ethical issues.

\section{A. S. R.: Could you tell us about your personal and professional relation with the journal History and Theory?}

E. K.: As I mentioned earlier, History and Theory was very important during my graduate studies and was in some ways the intellectual center of my work. I spent hours reading the journal and arguing with my peers and professors about the topical issues or debates of the day. Thus it really is a dream come true to now be the editor. When I applied for the position at Wesleyan University, it was with the hope that I could eventually join the editorial committee and to my good fortune I was allowed to do so in 2003. Since then I have been active with the journal and, as in graduate school, it is the center of my intellectual life. But beyond this, I have developed great relationships with the other editors, Gary Shaw, Vijay Pinch, Laura Stark, and Matthew Specter, as well as with members of our editorial board. I should also say that Brian Fay, Phil Pomper, and Dick Vann were incredibly influential figures for me, especially Brian who is still a wonderful mentor and friend. And I would be remiss if I didn't mention our executive editor Julia Perkins who really makes the journal run. I guess the point is that History and Theory is both my intellectual home and also like a family to me.

\section{A. S. R.: What are the main challenges of History and Theory today?}

E. K.: There are a number of challenges facing History and Theory today. I think first is the precarious position of philosophy of history in the discipline of philosophy. Frank Ankersmit has written about this and it seems to be the case that fewer and fewer philosophers are being trained to work in this field. I would say that we need to start thinking differently about what counts as philosophy of history and perhaps look to philosophers engaging in questions of temporality or fields such as virtue ethics. Still, we need to find ways to direct philosophers toward a sustained interest in history and the past. A separate but important challenge has to do with the expansion of the field of theory of history beyond the western canon. Over the last five years we have worked hard to engage with scholars from China, India, and South America in order to pursue a larger global conversation about history and theory. But we also realize that the desire to encourage a more global conversation, laudable as it is, is also rife with difficulty. As Vijay Pinch and I have argued, "The West" is a difficult, slippery geo-cultural signifier; more so the "non-West." Why else the compulsion to put them in scare quotes? Where does the West end? Especially when such a substantial portion of the journal's global, and putatively "non-Western," readership inhabits intellectual cultures that themselves have emerged, historically, as a result of intellectual dialogue and political exchange with the West-uneven though that dialogue and exchange may have been. Even those pockets of intellectual culture 
that resolutely resist the West cannot help but, by virtue of their resistance, be shaped by it.

5. A. S. R.: As we know, Hayden White's work is famous worldwide because he was able to demonstrate the way tropes of fiction work in historiographical texts. In your work, I perceive a shift, where you use fictional texts to elaborate latent historical experience. Could you describe how historians can use literary texts in order to challenge the canon of historiographical studies in ways that are different from those of Hayden White? In short, how can we think of new relations for History, Philosophy, and Literature to open ourselves to new understandings and experiences of historical time?

E. K.: Hayden White's work is incredibly important for thinking about the ways that history, especially historical narratives, function like literature. I think it is a mistake to infer that this means that for White the historical text is a pure fantasy, but instead to understand the way that the historical text is a particular form, or perhaps genre, of literature itself. As you note, my interest departs or perhaps builds on that of White, insofar as I am interested in what literature and specifically literary fiction can tell us about the past and the ways we think about the past. In short, the ways that the past haunts history. For most historians, literary fiction is used solely as evidence of something or for something. It is important not in and of itself, but as evidence in the way that one could argue 216 that the work of Erich Maria Remarque in France or Ernst Jünger in Germany can inform us about the cultural or intellectual climate in interwar France or Germany. In the way that Shakespeare's plays can tell us about gender roles in Elizabethan England or Machado can tell us about nineteenth century Brazil. This is of course a rather utilitarian argument about the value of literature and literary fiction but I would contend that the rise of new historicism indicates that this valuation extends beyond the disciplinary guild of historians into the realm of literary scholars as well. To my mind, the issue that most troubles the modern historian is the possibility of an inversion whereby the matters of fiction, the imaginary or the unreal, take priority over the matters of fact, the "as it really happened", the surety that we understand and comprehend the strange artifact that is the past. If history is to take itself as a "science", surely it cannot be more akin to literature than to neuroscience! Thus many historians only find value in works of literature as matters of fact, evidence, in the service of demonstration.

But I want to approach the issue from the other side and suggest that literature and literary fiction can serve to challenge this utilitarian argument by troubling our underlying assumptions about what is "real", about facts and fictions and about our own utilitarian and materialist assumptions. When I use works of literature as the instrument of a critical engagement with history I am often asked why would I choose works of literary fiction to make my point rather than historical ones. The answer is two-fold. One aspect hinges on the historian's obsession with the fantasy of a historical science and the related overemphasis on empirical evidence. With literary fiction, the evidentiary 
stakes are lower... it does not matter whether it is "true or false" or whether the events happened at all. Thus the historian is willing to engage in an argument about the ghost-like nature of the past demonstrated via the work of an author such as Charles Dickens in a manner very different than an attempt to use a history of ghosts, for example, where the historian would be caught up with the question as to "whether ghosts did or did not exist", rather than what the ghost can tell us about our relation to the past. But this lowering of the stakes, this "not mattering" turns out to matter very much insofar as literature can be mobilized to critique and question our historical assumptions about the privileged status of "facts".

This is to say that literary fiction does not have to be "useful" in this utilitarian sense and it does not have to coincide with what we take to be the "real". Literature activates a perpetual ambiguity that is also the locus of meaning because it resists any kind of totalizing view. Thus as a matter of fiction, literature troubles the tranquility that comes with the assumption that what we know as a matter of fact is a completely stable entity. This is a scary thought for historians who fear such a move will lead to a ghostly ballet of moral and empirical relativism, but to go that far would simply be to invert the hierarchy by privileging fiction entirely over fact. Instead, I am interested in the ways that literature compels us to engage with the role that imagination plays in creating the coordinates by which we posit history as meaning. Here the utility of literature is its obdurate resistance to the logic of utility. What matters most is that it does not matter in any of the senses argued by moral philosophers, neuroscientists, or literary historians. Instead, what matters are not the evidentiary outcomes of matters of fact but the seemingly endless questions engendered by matters of fiction.

This brings me to the second aspect of my response. Whereas Hayden White was looking at the form of literature to illuminate its relation to historical narratives, I use literary fiction as a privileged site that exposes the way the past haunts history. The past by definition is gone and thus has no ontological properties or one might say that it has a latent ontology that is activated when we do history. But this activation of the past is always partial leaving the remains hidden or dormant. This is a past that is absent but haunts us and can return in ways that disturb our conventional historical narratives and understanding of what the past and history is. To my mind, literary fiction is one site where this haunting is particularly strong but historians are not especially attuned to reading literature for history in this way or perhaps they aren't allowed to do so. In any event, on my reading literary fiction can expose our relation with the past without closing it off or limiting future possible readings. This is history as a rigorous understanding of the past that is nevertheless open to continual revision but it also asks us to rethink spatial-temporal coordinates by which both philosophers and historians situate past events as "history".

\section{A. S. R.: You are quite critical of the realistic tradition of historical studies that is based, in your terms, in an ontological, realistic approach to history limited by an analog ceiling. But you are critical as well of Hayden White's approach}


regarding a sharp discontinuity between language and reality. In the end, you engage critically with the theory of presence as promulgated by Hans-Ulrich Gumbrecht, Frank Ankersmit, and Eelco Runia, since you state that the theory of presence's belief in real contact with the past lies in a conformist approach to history. So, how do you place yourself in the scenario of the Theory of History? Could you speak about your recent book "Haunting History: Deconstruction and the Writing of History"?

E. K.: There are several aspects to this question, so I'll try to address them systematically. I will start with my criticism of the conventional, or what I call the ontological realist, understanding of history because I believe that Hayden White, Hans-Ulrich Gumbrecht, Frank Ankersmit, Eelco Runia and I are all critical of this position even if we may disagree on the details. I define ontological realism as a commitment to history, as an endeavor concerned with events assigned to a specific location in space and time that are in principle observable and as such are regarded as fixed and immutable. Here the historian accepts that there is a possibility for epistemological uncertainty as to our understanding of a past event, but this is mitigated by the ontological certainty that the event happened in a certain way at a certain time. Central to this position is a commitment to empirical data that serves as something of a false floor to hold it. In the end, getting the past "right" is a question of historical method. So one question we need to ask is what holds the ontological certainty of the past event given 218 the possibility of epistemological uncertainty in recounting that event? Most conventional historians either avoid or defer this question working purely on the assumption that method is sufficient to bring the past into the present. But the past event cannot be made present and thus any reappearance is the untimely visitation of a ghost. This leads to a more troubling question about the category of ontology itself and specifically the ontology or hauntology of the past.

The place where I disagree with Hayden White as well as Hans-Ulrich Gumbrecht, Frank Ankersmit, and Eelco Runia is not in the criticism of conventional disciplinary history but whether history as a discipline should be discarded in order to productively engage with the past. To my mind, White, Gumbrecht, Ankersmit, and Runia each argue for a kind of divorce between theorists or philosophers of history and historians with the former taking up the investigation of our individual and/or collective relations with the past and the latter languishing in the archives chasing ontological realist dreams. For Hayden White, this has led to a constructivist approach predicated on the role of language and narrative where the past is always and necessarily absent. For Gumbrecht, Ankersmit, and Runia, this has led to a suspicion of the mediating role of language or discourse in favor of an unmediated relation with the past via "presence", where the past is absolutely present.

As you say, I am sympathetic to the "presence" paradigm, especially regarding the ways that the past touches us even if we cannot touch it. But I am also deeply critical of the presence model in two ways. First, I am troubled by the passivity required in the presence model. At times, the movement of 
"presence" actually forecloses the possibility of change and justifies the status quo through its claims to produce unmediated access to the past via a return to the real. This happens in Runia's discussion on Abu Ghraib, in Gumbrecht's emphasis on Heideggerian Gelassenheit, the patient waiting or letting things be, and for Ankersmit as well insofar as the past is literally present albeit through a radically individualistic and seemingly incommunicable character via "sublime historical experience".

Second, and I think ironically, the emphasis on the material presence of the past in the present is strangely similar to that of the ontological realist approach insofar as both are predicated on a logic of presence. The ontological approach of those philosophers of history, whose focus is our historical mode of being in the present, and the epistemological approach of those historians, who focus on the importance of method for ascertaining the reality of the past, each emphasize what is present and not on absence. Runia, Gumbrecht, and Ankersmit do so by arguing for the presence of the past in the present. Conventional historians do so by arguing for the enduring and recoverable presence of the past as past.

I embrace White's emphasis on language and aspects of the presence model, but my hauntological approach to history is one that follows the play of presence and absence, of presence as absence, and absence as presence. In contrast to the search for origins or the material past made present, I look to Derrida to engage with and make explicit the perturbations that the past returned convokes. In Archive Fever Derrida discussed our relation with a tradition or legacy as what he called a "performative repetition", in which the interpretation of the archive also involved interpreting and inscribing oneself into the archive so as to have a rightful place in it. In this way, Derrida sees the relation with the past as a process of self-inscription wherein one reads and interprets the archive of the past in order to create a space for oneself in it in the present. But at the same time the traces of the past carry with them a force that breaks with their context and their moment. This opening onto the relation of presence and absence through a Hauntological approach to history predicated on a logic of différance accounts for the entangled relation of presence and absence without privileging one over the other. This is all to say that the historical deconstruction at work in my approach seeks to operate with elements of "constructivism", but without giving up claims to engage with the "real".

7. A. S. R.: You are quite critical of the tradition of historiographical studies concerning beliefs that are the basis of practices of historicization. You criticize both the realistic approach of historians regarding the possibility of locating things in space and time, and the limits of the forms - articles, monographs, dissertations - that reinforce these perspectives. Could you build a bridge between your theoretical perspectives regarding Theory of History and the contemporary challenges faced by digital humanities? You deal directly with these problems in chapter 4 of "Haunting History", "The Analog Ceiling". Please, tell us a little bit about it. 
E. K.: I can build on my previous answer because in my view the current dominance of ontological realism in the historical profession is no longer justifiable based on our current understanding of the past. Alun Munslow made this point several years ago when he argued that proponents of this view often hold it while simultaneously making concessions to philosophers or theorists of history in regard to the properties of the past or issues of writing and representation. In this light we can say that in the practice of actually doing history-research, writing, teaching-conventional historians both acknowledge and ignore, if they do not dismiss outright, the criticism, concerns and constructions articulated in theory of history over the last 50 years. This willful ignorance is what I call the Analog Ceiling, because of the ways that current practices in academic publishing reinforce the use of ontological realism as the only viable mode of doing history. The ceiling functions because it allows one to argue that even though the past may not really correlate to the narrative reconstructions of ontological realism, this form is nevertheless the best analogy to make the past intelligible, understandable, and comprehensible. This argument also contends that the constraints of publishing, advanced degrees, and tenure all make this the best and most viable format for writing about the past and for "doing" history. Thus the argument for ontological realism as the most useful analogy to represent the past is reinforced by the analog limits of traditional publishing that shepherd historians toward the form of realist fiction. We are restricted from innovation because of the ways that 220 the assumptions of ontological realism and the limitations of analog publishing practices serve to substantiate each other as necessary.

Even with innovations in the theory of history and in the digital tools/ formats available to us, we are in danger of using them to simply replace the old ones. Thus the article on-line looks exactly like the one published in the journal. The e-book is indistinguishable from the codex. We are hitting our heads against the analog ceiling rather than crashing through to see how these innovations in theory and form can change the way we research, write, and teach about the past. The way we do history. But the discipline of history is facing a paradigm shift and historians whose mindsets were formed and constrained by print must now confront the changes that digital media makes in every aspect of their discipline. One part of this shift is the possibility of reconceptualizing historical works as multimodal, multi-temporal, and multi-media so as to resist the presentation and restrictions of a monolithic temporal narrative. In these models, time and space is, or can be, out of joint and it is in this way that new forms align with a hauntological narrative reconstruction focused on non-simultaneity, divergent historical paths, and the instability of time. Here we are talking about the multiply heterogeneous iterations of a narrative form that does not unfold in a strict linear fashion but is threaded through itself in a nonlinear polysemic topology. One that defies the smooth continuous strategies of ontological realism but coincides much more closely with what we know about space and time and how, to my mind, we should think of the latent ontology of the past. Such a narrative accommodates an understanding of what I call the past as something that is, as 
present and absent at the same time, as something and nothing entangled in a seemingly impossible way where the iterative position of the historian is woven into the past and the present such that it also presses upon the future.

8. A. S. R.: In the chapter 3 of "Haunting History", "Chladenius, Droysen, and Dilthey: Back to Where We've Never Been", you explore how these authors faced the crisis of representation, demonstrating how they attempted to establish historical stability by recurring to theodicy or historical method. How does your reading of these authors show that the main problem of historiographical studies is looking for present stability? What is the risk of stability?

E. K.: One reason I look to the German historicist tradition is because these thinkers are often used to justify or validate current theoretical or methodological approaches. In the book I cite a forum in the American Historical Review where the American intellectual historian David Hollinger references Dilthey to concede the fallibility of the historian but not the definite nature or retrievability of the past. In a similar vein, Felix Gilbert asserts that "Droysen is closer to the modern historical approach than many historians of the generation which followed him" (GILBERT 1983, p. 336) while Blanke, Fleischer, and Rüsen can claim "for Droysen it is not possible to endanger [the empirical character of history] for he still explains the historical research epistemologically and finds the beginnings of his philosophy of history in the epistemological foundations of historical studies" (BLANKE; FLEISCHER; RÜSEN 1984, p. 350). And more recently, Chladenius's concept of the viewpoint or Sehepunkt has been deployed in the service of an argument similar to Hollinger's, wherein the fallibility of the historian is given but not the instability of the past event. Each of these serve to determine the past as a stable and fixed object that can be represented accurately so long as the historian adheres to the proper methodological approach.

The key issue here is that, as a result of this approach, the instability of the past is replaced by a sense of fixity that is based on the representation and re-experiencing of the past event. It is one's belief in the continuity of events, as if they really happened as such, that is proffered, not the reality of those events. But the priority of the representation in securing this belief is effaced in favor of the holding power of the originary event itself. Once the proof of the historical account is considered to be its adherence to the ontological reality of the past event, the role of the historian in assembling the fragments into a whole is demoted to one of epistemological method rather than ontological construction. That is, the role of the historian in constructing what is to be considered the ontological reality of the past event is effaced. The repercussion is that the historically contingent nature of the particular historical representation is considered to be valid for all time and with this other possible historical understandings or representations are closed. But the fiction of a stable past is the fiction of a stable present.

What I try to demonstrate is the way that the positions of Chladenius and Droysen are predicated on a theological understanding of order and stability 
wherein the past, and access to the past, is held in place by the higher power of God. The instability of this position absent the presence of God becomes clear in the work of Dilthey, but most modern historians and theorists substitute historical method for the religious positions of Chladenius and Droysen. This leads us to a tautology of sorts because it is not the presence of God that provides the absolute ground for accessing the past through proper methodology, but the ontological reality of the past that now becomes the guarantor of the historical endeavor which itself defines what the ontological reality of the past should be. Conventional historians and some theorists of history have focused on the epistemological issue of a universally valid rigorous method to stabilize this investigation into the past, but in doing so the task of creating a universally valid methodology is presented as something that has already been accomplished. This despite the fact that neither Chladenius, Droysen, nor Dilthey was ever able to achieve this ideal nor is it likely that such an ideal could be achieved given Chladenius and Droysen's reliance on a theological scaffold and Dilthey's emphasis on the historicity of the subject.

But such a "failure" can only be so considered if one's goal is to argue for the rigid stability of the past. Instead, I try to look at these figures to think about the instability of the past. Chladenius, Droysen, and Dilthey all placed a heavy emphasis on the methodology of the historian in response to the instability unleashed by the realization and articulation of the historian's own role as a historical being for whom history is an issue. By using the work of Derrida I

222 pair the standpoint or perspective (the historically conditioned moment from which we begin our investigation into history) with différance in order to place this entry point into the hermeneutic circle into question. Indeed, the very notion of stability is placed in question by the complex relation between the historian operating within the context of their historical moment and the sources (Quellen), remains (Überreste), or monuments (Denkmäler) through which the past haunts the present and the historian attempts to understand the context of the past. For historians, a context is never absolutely determinable because it is always gathered/ascertained within another context. If we really want to think with the past, rather than simply try to control it, we must learn to focus on its instability and the ways that the past haunts history.

9. A. S. R.: Could you speak a little about the book that you are working on now, "The Myth of Emmanuel Levinas"?

E. K.: As originally conceived, this project focused on Emmanuel Levinas' Talmudic Lectures presented in Paris, France, between 1960 and 1990; the origins of Levinas' turn to the study of the Talmud in the years following World War II; and the reception of Levinas' Talmudic Lectures. The thrust of the work was to dismiss the "myth" of Levinas as a Lithuanian trained Talmudic scholar and explain the ways and reasons that Levinas came to study the Talmud in the aftermath of the Shoah. A key component of this trajectory was to also demonstrate how Levinas has influenced modern Jewish thought by establishing a post-rabbinic chain of 
tradition that allowed Levinas and his successors to re-establish the Talmudic tradition in the wake of the Shoah, but devoid of any actual rabbinic authority. Thus the project was initially about issues of intellectual legitimacy and the creation of intellectual authority and in many ways it still is. But as the project began to take shape in chapter form I became increasingly unhappy with the product. In a review essay for History and Theory and in an article on "Freud and Levinas" I explored the issue of the relation and biases of the project of history to the claims of religion and then found myself repeating those biases in my work on Levinas. At that point I decided to re-think the architecture and presentation of the book in an attempt to simultaneously present a cogent intellectual history of Levinas's Talmudic Lectures that would provide a contextual reading of the sources and causes for his turn (essentially the original project), but that would simultaneously offer a counter interpretation that allow Levinas's transcendent claims to stand in "good faith". This is to say that while I believe a critical intellectual history of the context surrounding Levinas's turn to Talmud and construction of an "ethics of the other" (an immanent secular history) is both warranted and necessary, I think it is equally important to engage Levinas's presentation of the transcendent nature of divine truth on his own terms and as an equally plausible interpretation.

One could look at this in the weaker sense of multiple perspective, but what I am trying to get at is the way the past is contradictory and unstable... different things at the same time. It was this aporia, this inherent contradiction in the project, that forced me to stop work on it and rethink how I approach the project of history, and this led me to write my recently completed book on deconstruction and history. In the Levinas book I employ the deconstructive or hauntological methodology I explicate in the deconstruction book.

10. A. S. R.: Could you present your thesis about historians' ambition to define history as a discipline in the same terms as those of the hard sciences and how it relates to neo-liberalism? In short, could you speak about your recent article "Just the Facts: The Fantasy of a Historical Science", published in the journal "History of the Present"?

E. K.: One aspect of the historical discipline that has always fascinated me is the way that historians regularly offer paradigms for discerning the truth of the past that they know and admit are unattainable and then efface those aspects of their model that expose the limitations and inadequacies in the histories that they write or tell. I think this is what is at play in the recent turn to "science" among historians in the United States through neuro-history, evolutionary history, biological history, or Big History. This most recent infatuation with science is new and troubling because to my mind it serves to close off discussion and debate between historians and scientists rather than promote it, but also because the impetus for it is, to my mind, primarily a financial one. One ill effect is that the purported rapprochement or conversation between biology and history is actually quite one-sided because it takes place on the nomothetic 
grounds ascribed to science rather than through an investigation into the ways any natural law can be rendered problematic through historical inquiry. But there is a larger and more pernicious contradiction at work. Proponents of a scientific history argue that by collapsing the distinction between the natural and the human sciences they eliminate the privileging of the written text and thus remove the cultural and intellectual biases that sustained the "great men" narratives of the past. But what is presented as a democratizing sentiment is actually deeply troubling because of the way it evacuates politics. The critique of reason as the exemplar of the human is one that has animated many feminist, queer, and critical race theorists and historians who have worked with this notion since at least the 1970s. The false promise of a scientifically determined universal humanity ignores these achievements and depoliticizes history and historiography.

But this leads to a larger question. Why should we give pride of place to the hard sciences, when this discourse and set of disciplines is so fraught with problems of hierarchy, gender bias, and presentism? At the most cynical level my answer is that despite the many good intentions of those scholars seeking to expand the horizons of the historical discipline, the question is primarily an economic one. Over the past twenty years, historians have moved increasingly toward affiliation first with the social sciences and then with the hard sciences; such movement tracks the rise of the STEM initiative and the perceived crisis of the humanities. It is not surprising or even a coincidence that as federal, state, and local governments have invested increased amounts in the "hard sciences", enrollments in the humanities and history in particular have declined. The pursuit of capital stimulates ideas and paradigms, and one result is that historians now run toward science in search of those funds. To my mind, the interpretative choices of neurohistorians or the Bill Gates-supported proponents of Big History must be seen in this light, whatever the merits of their particular interpretations. Such choices also point to the way that their supposedly insurgent position against the mainstream of historical work is actually, in the larger sense, aligned with the most mainstream trends in emphasis and funding. Here, the logic accords with that of neo-liberalism insofar as we see the dissolution of traditional divisions of labor: the labor of the historian is consolidated with and replaced by that of the biologist. To my mind this is not a rapprochement, conversation, or interaction between history and the sciences but an unconditional surrender. By ceding ground to this fantasy of science, historians also cede the space for critical intervention that is the strength and heart of our discipline.

11. A. S. R.: I can find some similarities between your reading of the limits of disciplinary historiography, and your proposal to explore how the past haunts the present, with Reinhart Koselleck's theory of modernization and the notion of layers of time. However, despite worldwide academic recognition of Koselleck's work, it is possible to argue about the limitations of his conceptual history for the transmission of meaning as a template for historiographical investigation. Here, the "paradigm of presence" that you know well presents other possibilities 
of investigation for theorists of history and intellectual historians. I would like to know how you see the importance of Koselleck's work for your approach and for historiographical studies in general.

E. K.: My work is situated within the framework articulated by Koselleck wherein our modern understanding of "history" is conceived as a force in itself causing the kinds of changes in social arrangements that had formerly been referred to as divine, metaphysical, natural, or human. But I argue that in this hypostatized domain of history as a causal force, the relations between the past, the present, and the future began to overlap or break down. Past events are brought "back" to the present through the work of history but other aspects of the past haunt us and the very history to which we cling. These are the ghosts of things inadequately remembered, badly buried, or incompletely expunged from the record being rigorously researched by traditional historians and that so often support dominant ideologies.

Thus it is Koselleck's focus on multiple or disjointed temporalities that I find so welcome. Helge Jordheim presents Koselleck as offering a radically different theory of overlapping temporal structures and layers, synchronicities and non-synchronicities (JORDHEIM 2012). Jordheim's emphasis is on the issue of periodization in Koselleck, but my interest is on the overlapping temporal structures and the friction between these structures that expose what Koselleck calls Ungleichzeitigkeiten, noncontemporaneity or non-synchronicity. The phenomenon of Ungleichzeitigkeiten occurs at moments when elements of a later time are introduced as contemporaneous with the event depicted or represented. What is fascinating is that for Koselleck, this moment of disjuncture where time is out of joints points to the coincidence and non-coincidence of the historical telling with the past event. And to my mind, these moments out of time are the site of hauntology, a slippage between past and present. This grinding of gears when multiple temporalities overlap exposes the way that traditional historical accounts tend to "freeze" the events depicted even as the event is continuously reworked and altered by the telling itself. Koselleck presents this specifically in relation to his methodology of Begriffsgeschichte or Conceptual History. By focusing on the concept (and especially the ways that concepts are reoccupied, Umbesetzung), one steps in and out of the present and unsettles the assumptions inherent in the historical investigation. In this way, the method of Begriffsgeschichte breaks free of what Koselleck calls "the naïve circular movement from word to thing and back" (KOSELLECK 2004, p. 86). But I think that Koselleck's notion of reoccupation can be pushed further if we think of it as a means to understand what Derrida refers to as "inhabiting a tradition". What's more, one could align the disjunction of non-simultaneity with the Derridean aporia in order to negotiate the constitutive dissymmetry of a past that is. The temporal paradox of how something can be present and absent at the same time is addressed by the deconstructive approach. This is hauntology as a theory of multiple temporalities and multiple pasts that all converge, or at least could converge, on the present. 
12. A. S. R.: Considering our conversation about the advantages of thinking the Theory of History as hauntology, I would like to address briefly some issues regarding the challenges of contemporary Brazilian professional historiography. Brazilian professional historiography has been working at the historicization of our haunting pasts, such as the history of slavery between the sixteenth and the nineteenth centuries and the history of dictatorship in the 1960s, 70s, and 80s. However, despite the historiographical historicization, these pasts still haunt us in the present. The issues of racism and the claims of a non-democratic right wing in Brazilian society are well known internationally. How can professional historians address these subjects without taking for granted that it is possible to historicize these pasts? Could you explore some strategies that professional historians can use in order to deal with simultaneous specters, considering whether the unilateral emphasis on one can give room for the appearance of the others?

E. K.: I guess I should start with the caveat that I am not an historian of Brazil and what I know of Brazilian historiography has come from recent articles on the subject. But I think your question points to some of the key issues I address in my book Haunting History. One of the problems with traditional approaches that ascribe to the ontological realist position is that even in moments when they open new possible paths of interpretation, they simultaneously close off others. So one might consider traditional European historiographical accounts of Brazil 226 as restricting the sorts of stories or accounts that can be considered "history" or proper historical sources. But promoting these sources and constructing new "histories" that account for the history of slavery or indigenous peoples will not be sufficient if each of these diverse and differing narratives seeks "firmer ground" on which to set their own identity. When identity politics comes into play what I would label a truncated deconstruction appears and simply inverts the power dynamics rather than actually destabilizing them. Here the rejection of deconstruction is the repression of the realization that there is no stable foundation. From this perspective, the organizing principle of conventional historical investigation and the relation with dominant or competing ideologies/ political positions is never truly put into question but simply redeployed to make the "colonizer" the "colonized". What I refer to as the "analog ceiling" reinforces these limitations by constraining our historical narratives within the realm of realist fiction and linear narrative. By contrast, a hauntological approach acknowledges the way that these competing, conflicting and polysemous pasts are always already inside of each other and encourages exploration of new forms to account for them, even if it never seeks to contain them. Far from implying the death or abdication of the author, deconstruction for history requires a strong and careful historian whose rhetorical style guides the reader along the poros that simultaneously introduces and acknowledges the aporia. It is a giving and taking that makes the reader aware of the openings at play and the polysemous nature of the past. This is all to suggest that the conventional history of Brazil articulated by professional historians is haunted by a past replete with ghosts 
that disturb that very history: the ghosts of indigenous peoples, of conquest, of slavery, of dictatorship and political unrest. A fuller presentation of the history of Brazil would be one that allows the space for these ghosts to appear even if their appearance is profoundly disturbing because of the ways they compete with, contradict, and trouble one another.

This cannot be simply perspectivalism or hermeneutics because it is not only the viewpoint of the historian in the present that acts upon history but also the past itself, which presses upon the present independent of our conscious will, intention, or desire.

13. A. S. R.: Between August 23 and August 26, 2016, the $2^{\text {nd }}$ INTH took place in Ouro Preto, Brazil. We had the opportunity to meet specialists in the fields of Theory of History, History of Historiography, Philosophy of History, and Intellectual History from around the world. Among many interesting things that happened at the conference, I highlight a first meeting to create a Latin American Network dedicated to gathering specialists committed to thinking about history. You had the opportunity to participate in the Closing Remarks Roundtable, whose purpose was to address the main intellectual challenges that we faced at this meeting and will face at future ones. Could you speak a little bit about your impressions regarding the $2^{\text {nd }}$ INTH? What do you think about the solidification of INTH and other international networks with regard to the future of studies in the mentioned fields?

E. K.: I thought the meeting was wonderful and I was especially impressed by the strength and originality of the graduate students and young scholars working in the field. In particular, it was a great opportunity to meet scholars from South America, Central America, and Mexico and to cultivate new relationships. I am very enthusiastic about the creation of the Latin American Network because of the creative, vibrant thought I encountered at the conference. This all bodes well for the future of the theory of history.

In terms of the conference content, I was struck by a tension announced in the more Nietzschean side of the conference theme: "On the Advantage and Disadvantage of History for Life". The great advantage of the INTH endeavor is the desire to find common ground, to bring together scholars with an interest in theory and philosophy of history from around the globe to engage with each other. Such interaction is undoubtedly a positive thing, but the desire to find a common ground is not unproblematic. There is always a danger when one embarks on the project of comparison that the project will be based on a control group that is taken to be the "norm" and against which all other groups must be measured. In our conference, that might be the Western concept of "history", Koselleck's concept of modernity, or Halbwachs' model of memory. The danger here is that the claim to common ground is actually predicated on a theoretical imposition.

Sanjay Seth made this clear when he asked whether the historical code, the one designed in the West, is adequate to the task of non-Western histories? 
And Guillermo Zermeño offered a powerful argument as to how historians and theorists of history might construct an understanding of history attuned to our common endeavor but also what differentiates each place and the particular forms of history that come from each region. Of course, this too presents dangers of entropy, distance, and incommensurability.

This conflict between the desire to find commonality while also embracing difference is an unresolvable one but, to my mind, the future of the philosophy of history lies in this intersection and in this tension. What's more, I would say that it is theory that provides the meta-language to address both sides.

\section{References}

BLANKE, Horst Walter; FLEISCHER, Dirk; RÜSEN, Jörn. Theory of History in Historical Lectures: The German Tradition of Historik, 1750-1900. History and Theory, v. 23, n. 3, p. 331-356, 1984.

DERRIDA, Jacques. Archive Fever: A Freudian Impression. Chicago: University of Chicago Press, 1998.

FRIEDLANDER, Saul (Org.). Probing the Limits of Representation: Nazism and the "Final Solution". Cambridge, MA: Harvard University Press, 1992.

GILBERT, Felix. The New Edition of Johann Gustav Droysen's Historik. Journal of the History of Ideas, v. 44, n. 2, p. 327-336, 1983.

228 GHOSH, Rajan; KLEINBERG, Ethan (Org.). Presence: Philosophy, History, and Cultural Theory for the Twenty First Century. Ithaca: Cornell University Press, 2013.

JORDHEIM, Helge. Against Periodization: Koselleck's Theory of Multiple Temporalities. History and Theory, v. 51, n. 2, p. 151-171, 2012.

KLEINBERG, Ethan. Generation Existential: Martin Heidegger's Philosophy in France, 1927-61. Ithaca: Cornell University Press, 2005.

. Haunting History: for a deconstructive approach to the past. Stanford: Stanford University Press, 2017.

. Just the facts: the fantasy of a historical science. History of the Present, v. 6, n. 1, p. 87-103, 2016.

KOSELLECK, Reinhart. Futures Past. New York: Columbia University Press, 2004. 